\title{
Criminal Profiling: Framing of Charges Upon Sexual Offences
}

\author{
Muhamad Helmi Md Said ${ }^{1}$, Haziratul Aqilah Huzailing ${ }^{1}$, Vithiya Thevvi Paneerselvam ${ }^{1}$, Sabrina Chu Soo \\ Woon ${ }^{1}$, Amir Redza Ahmad Fuad ${ }^{1}$, Maryam Kamaruzaman ${ }^{1} \&$ Maisarah Mustaffa $^{1}$ \\ ${ }^{1}$ Fakulti Undang-Undang, Universiti Kebangsaan Malaysia, Bangi, Selangor, Malaysia \\ Correspondence: Muhamad Helmi Md Said, Fakulti Undang-Undang, Universiti Kebangsaan Malaysia, Bangi, \\ Selangor, Malaysia. E-mail: mhelmisaid@ukm.edu.my
}

\author{
Received: May 21, $2021 \quad$ Accepted: August 4, $2021 \quad$ Online Published: September 1, 2021 \\ doi:10.5539/jpl.v14n4p103 URL: https://doi.org/10.5539/jpl.v14n4p103
}

\begin{abstract}
In criminal profiling in cases involving sexual offences, the charges must be drafted with a great degree of precision. Every sexual offence has its individual elements that need to be fulfilled before a charge is preferred. There are instances where the defects in charges are rendered to be fatal to the prosecution's case and instances where Section 422 comes to aid and cures the irregularities in the charge. The objective of this research is to identify the common features that render a charge defective in cases related to sexual offences, the effect of the defects. It also aims to analyse the courts' approach to determine whether the particular defect is fatal or curable and suggest solutions in handling defective charges to achieve the ultimate purpose of ensuring that justice is served and eliminating any prejudice towards the victim accused. Generally, charges for sexual offences are rendered defective when the charge fails to specify the kind of act which constitutes the alleged sexual act and the related provision. In order to achieve the objectives of this research, qualitative research was conducted through library research, case studies and data analysis. The possible solutions to handle a defective charge would be to determine whether a particular defect in itself would cause a miscarriage of justice by misleading an accused and stripping off the rights of the accused to defend himself. Since the purpose of a charge is mainly to notify the accused, as long as the defect in the charge did not mislead the accused in defending himself, the defects are considered mere irregularities.
\end{abstract}

Keywords: criminal profiling, defective charges, sexual offences, curable irregularities, criminal procedure

\section{Introduction}

Criminal profiling is vital for framing the charge in sexual offences. Thus, a charge serves the purpose of a notice or intimation to the accused, drawn up according to the specific language of the law, giving clear and unambiguous or precise notice of the nature of accusation that the accused is called upon to meet in the course of a trial. VC Shukla v State through CBI 1980 Cri LJ 690, Jackson J in $R v$ Mohamed Humayoon Shah (1874) 21 WR Co 72 asserted that a charge is a notice to the accused which must be conveyed with sufficient clearness and certainty and which the prosecution intends to prove against him and of which he will have to clear himself.

In Public Prosecutor v Chung Tshun Tin \& Ors [2008] 1 MLJ 559, Hamid Sultan JC in his judgment at page 580, stated that:

"It is a fundamental principle of criminal law that the accused should be informed with certainty and accuracy,

the exact nature of the charge brought against him. Otherwise, he may be severely prejudiced in his defence."

The ultimate purpose of a charge is to inform the accused of the nature of the offence that he allegedly committed with certainty and accuracy. In circumstances where the charge is unable to serve its purpose, the probability of it being prejudicial against the accused in presenting his defence is pretty high.

There are instances where a charge is rendered defective due to non-compliance with the law. Some of the defects, which are of minor severity, is held to be mere irregularities and can be remedied using Section 422 of CPC. In contrast, some defects could vitiate the prosecution's case. The objective of this research is to identify the common features that render a charge defective in cases related to sexual offences, the effect of the defects. It also aims to analyse the approach of courts in determining whether the particular defect is fatal or curable. This research is to offer solutions in handling defective charges to ensure that justice is served and any prejudice towards the victim and the accused are eliminated.

In order to satisfy the objectives of this research, qualitative research was conducted. The types of research that 
have been conducted in order to collect effective, complete and detailed data are library research, case studies and data analysis.

\section{Framing Charges under Ss 152, 153 and 154 of Criminal Procedure Code (CPC)}

The manner and content in which a charge shall be read have been explained in sections 152,153, and 154 of the CPC. Section 152 requires that every offence to a charge shall be stated. Section 152(1) states that the law provides a name for a specific offence. It would be enough if only the offence's name was provided. For an offence that does not have a specific name, the charge must include the definition of the offence in order to notify the accused of the wrong he has committed (Section 152(3) Criminal Procedure Code (Act 593)). This includes the law and section on that particular offence to be included as stated in Section 152(4). Under this provision, when a charge is read for the purpose of increasing punishment on a previous convict, the fact, date, and place of the previous conviction shall be stated (Section 152(6) Criminal Procedure Code (Act 593)).

A charge not only requires that the offence must be stated. Section 153 also requires the time and place of the alleged offence, as well as the individual involved in the offence, must be specified. In comparison, when it comes to a charge of criminal breach of trust or dishonest misappropriation of money, the charge shall merely mention the gross amount appropriated and the date on which the alleged violation was committed (Section 153(2) Criminal Procedure Code (Act 593)). Section 153(3) stipulates that when it comes to offence relating to the publication by electronic means, the place of publication where it is seen, heard or read must be stated. In circumstances where Section 152 and 153 still fail to notify the accused of the charge, Section 154 comes into the picture. Section 154 states that the manner in which the alleged offence was committed will suffice for that reason.

Generally, it can be concluded that the application of ss 152,153 and 154 are closely related to each other. Section 152 explains the form of charge and how it should be read together with what is contained in the particular charge. Section 153 elaborates further the need for particulars such as time, place, and person linked with the offence to also be included in the charge. In the case where ss. 152 and 153 are not even sufficient to notify the accused; section 154 will be used to clarify the matter to the accused. The charge shall then be read to the accused, to which he will be given the option to admit guilt or proceed to trial (Baljit Singh Sidhu, 2015).

The application of the three sections can be seen in the case of Mustafha Bin Abdul Razakv Pendakwa Raya [2017] MLJU 1723. The applicant contended that the charge to the accused was defective because the manner in which the offence was committed was not stated in the charge pursuant to Section 154 of CPC. The applicant further argued that the particular offence that the accused was charged with requires a more detailed explanation regarding the manner of the offence committed. The high court rejected the application on the grounds that Sections 152 and 153 have already been fulfilled and that there is no need for Section 154 to be invoked. This case illustrates that section 154 is only applicable when sections 152 and 153 fail to give sufficient notice to the accused.

The case of Mustafha is similar to the case of Rama Krishnan a/l Nallapuravu lwn Pendakwa Raya [2018] MLJU 1114. The court, in addressing the issue brought up by the appellant on whether or not the charge on the accuse is defective. A reference should be made to a judgement by Judge of Federal Court, Jeffrey Tan, in the case of Ravindran Ramasamy [2015] 3 CLJ 421, where he said that when the nature of the case is such that the particulars mentioned in ss. 152 and 153 do not give the accused sufficient notice of the matter with which he is charged, section 154 of the CPC will be used. In the case of Rama Krishnan, the court dismissed the appeal on the grounds that an error in the weapon used in the offence does not defect a charge as it does not affect the element of wrong committed by the accused. This shows that the subject matter of the case will not affect the charge against the accused so as long as the offence done is clearly stated in the charge.

As explained in the case of Mohd Ikhsan bin Ramli v Pendakwa Raya [2018] MLJU 2071, it is clear that an accused should not feel prejudiced by the non-application of Section 154 of the CPC. The said section clearly mentions S.152 and S.153. Section 154 is a general guide where a sufficient notice in S.152 and 153 is not fulfilled. In conclusion, it is clear that S.152,153 and 154 are complementary. Where a charge is stipulated clearly, as in S.152, $\mathrm{S} .153$, it is required that the particulars of the offence be included in the charge. If both fail to serve as a sufficient notification to the accused, Section 154 comes in to fill in the gap. This means that generally, a defective charge shall not call upon section 154 unless section 152 and section 153 have not been fulfilled.

Sections 152,153 , and 154 is vital in furnishing a charge of an offence. In the topic at hand, the discussion will focus on the charge of a sexual offence.

\section{Framing Charges under Section 152 of CPC for Sexual Offences under the Penal Code}

Under the Penal Code, the provisions related to sexual offences include sections 375 to 377E. When an accused is charged for committing any sexual offences under the stated provisions, a charge may be issued as the first step in 
the prosecution process. There are various issues that arise regarding the framing of the charge against any sexual offences, which will be discussed in Section 3.1.

\subsection{Requirements of Charge: Specific Offences to be Stated in the Charge}

In general, the requirements of a charge can be seen under Section 152 of the CPC. It is a general rule which states that in order for a charge to be sufficient and valid, the offence committed by an accused shall be stated in the charge (Section 152(1) Criminal Procedure Code (Act 593)). The accused must know the exact charge which he is called upon to answer and the offence he has been convicted (Jagar Singh v PP [1936] MLJ 114; PP v Dato' Seri Anwar Ibrahim \& Anor [2001] 3 CLJ 313; PP v Lee Pak [1937] MLJ 265). An example of a charge which is sufficient and valid is by stating the offences committed. As can be seen in Ratanlal and Dhirajlal, the model charge towards the offence of rape reads as follows:

"That you, on or about the day of , at , assaulted (or used criminal force to) $\mathrm{AB}$, a woman, intending to outrage (or knowing it to be likely that you would thereby outrage) the modesty of the said AB by such assault (or criminal force), and thereby committed an offence punishable under section 354 of the Indian Penal Code, and within my cognizance." (Ratanlal and Dhirajlal, 1997-1998)

Referring to the charge that was framed above, it can be clearly seen that the offence, which is rape that was committed by the accused, was stated together with the provision which provides such offence (Section 152(4) Criminal Procedure Code (Act 593)) under section 354 of the Indian Penal Code. The charge framed above could not be deemed prejudicial towards the accused by contending that the charge does not set out the manner in which the offence of rape was said to have been committed (Mohd Ikhsan bin Ramli v Pendakwa Raya [2018] MLJU 2071). The manner in which the rape was said to have been committed is only relevant when the nature of the case is such that the particulars mentioned under section 152 did not give the accused sufficient notice regarding the matter that he was charged (Section 154 Criminal Procedure Code (Act 593)). In short, as long as the specific provision related to the offence conducted was stated, it would suffice as a valid charge.

When the law does not give an offence a specific name, the definition of the offence will then be required to be stated to give the accused notice of the matter with which he is charged (Section 152(3) Criminal Procedure Code (Act 593)). This can be seen in Ab Malek bin Atan v PP [2002] 4 MLJ 84, where the accused was charged under S375 of the Penal Code for the offence of 'rape' and the court held that a particular limb under S375 is not required to be set out in order for the charge to be valid. In this case, Augustine Paul J contended that:

“... Section 152(2) of the CPC clearly stipulates that if the law which creates the offence gives it any specific name, the offence may be described in the charge by that name only. On the other hand, s 152(3) of the CPC provides that there is a need to state so much of the definition of the offence as to give the accused notice of the matter with which he is charged if the law which creates the offence does not give it any specific name."

Apart from that, in the case of Mohd Khairul Hisam Azis v PP [2019] MLRHU 321, the court had referred to sections 152, 153 and 154 of the CPC where it was stated that only when the requirements under section 152 and 153 could not be fulfilled, where the name of the offence committed and the particulars to time, place and person could not be fulfilled, would section 154 be stated. In other words, the manner in which the crime was committed must be stated. However, in this case, it can be clearly seen that all the act that was performed by the accused amounted to an act of gross indecency under section 377D of the Penal Code. Hence, the omission of not stating the particular act which amounted to gross indecency does not render the charge invalid. A similar view on the interpretation of section 152(2) and (3) of the CPC was also expressed in Krishnan \& Anor v Public Prosecutor [1981] 2 MLJ 121 by Salleh Abas FJ.

\subsubsection{Increasing Punishment by Proving Previous Convictions}

A charge may also include the accused's previous offences in order to increase the sentence that will be imposed on the accused. The fact, the date, and location of the previous conviction must be specified in the charge in order to increase the punishment (Section 152(6) Criminal Procedure Code (Act 593)). In Shah Reza Bin Zulkifli \& Ors $v$ Pendakwa Raya [2016] MLJU 576, the three appellants were charged for raping a victim under the age of 16 under Section 376(1) of the Penal Code separately, but they were tried together as the incident was in one transaction, involving the same witness. Another accused was charged under Section 377B for committing carnal intercourse against the order of nature. Azman Bin Abdullah J agreed on the application of Section 152(6) by stating that the law allows different sentences to be given to the accused with previous convictions. However, such acceptance comes with certain conditions that need to be fulfilled, which includes the date, time and offences must be stated, and the authenticity of such conviction must be proven. 


\subsection{Requirements of Charge: Particulars as to Time, Place and Person}

Apart from the conditions where the facts, date and place must be included in a charge to increase the punishment against the accused, an ordinary charge that is issued must also contain particulars such as the time and place of the alleged offence and the person involved in the incident (Section 153 Criminal Procedure Code (Act 593)).

The requirement to fulfil the elements was laid down in Mohd Hanif Kassim v PP and Another Appeal [2015] 3 CLJ 984. In this case, the defence counsel referred to section 153(1) of CPC, urging the court to consider that the charge failed to disclose sufficient information, in particular the time. Therefore, the charge was defective due to the insufficient information, in particular the lack of reference to time. It renders it a defective charge for noncompliance of section 153(1). However, there are exceptions to the provision, where the requirements are not necessarily included in the charge. If the time, date or place does not constitute an essential ingredient of the offence, mere non-compliance on the time, date and place will not vitiate the validity of charge (Dato' Seri Anwar Ibrahim v. PP \& Another Appeal [2004] 3 CLJ 737; PP v. Chettuvelu Nani [2007] 9 CLJ 533; [2007] 6 MLJ 621). In this case, both the accused knew that the offence of rape was charged against them. Hence, they were not prejudiced by their failure to comply with the requirements.

The judgment in the case of Mohd Hanif Kassim was then referred in the case of Mohamad Rizal Romlee $v$ Pendakwa Raya [2017] MLRHU 434, where the court expressed a similar view by quoting that:

"...the wordings in the charge were clearly stated. Although the exact time or date for the commission of the offence charged was not stated, in my opinion, the accused's fundamental right to defend the case against him was not prejudiced or derogated."

From both cases mentioned above, we could conclude that, from time immemorial, a date specified in an indictment is not a material matter unless it is an essential part of the offence (R v Severo Dossi [1918] 13 Cr App R 158; Law Kiat Lang v PP [1965] 1 MLRA 297; [1966] 1 MLJ 215).

\section{Framing Charges under S.152 of CPC for Sexual Offences under the Sexual Offences Against Children Act 2017}

The Sexual Offences Against Children Act 2017 (Act 792) was introduced to address the seriousness of sexual offences committed against children in Malaysia (Malaysia, Perbahasan Dewan Rakyat, Bacaan Kedua dan Ketiga, 4 April 2017, 28 (Dato' Sri Azalina Dato' Othman Said)). A child is defined under section 2(1) of the Act as person who is under the age of eighteen years, and by virtue of section 2(2), any reference to a child shall include a person whom the accused of an offence under the proposed Act, believes is a person under the age of eighteen years (Cooray, Manique, 2017).

The ultimate aim of the proposed Act is to provide better protection for children from sexual offences and to safeguard children's interests and well-being, and ensure successful deterrence (Cooray, Manique, 2017). This is because the protection of children provided under the Penal Code is not enough. It is an old law that is insufficient to cater for all forms of sexual crimes, such as grooming, molestation and child pornography. Realising that a law on the physical and digital spectrum of sexual offences against children was urgently needed, in April 2017, the Act was passed by the Parliament (Rosli, N., Zubaidi, N. H. A., \& Dusuki, F. N, 2019). The Act contains seven parts with twenty-eight sections. It covers all aspects, including the corroboration of child victims' testimony and the creation of a national special court for child sexual offences.

Usually, in the case of sexual offences, the law does not prescribe the specific name of the offence. Therefore, pursuant to section 152(3), if the law does not define the offence with a specific name, there is a need to comprehensively state so much of the definition of the offences to give the accused notice of the matter with which he is charged. For example, in the case of Helerry Bungkok v PP [2019] 10 MLJ 308, the accused charge paper runs as follows:

"That you, between 30th August 2018 at about 11.00 PM to 31 August 2018, at about 1:30 AM at the farmhouse near Simpang Yong, 96800 in the district of Kapit, in the state of Sarawak had physically sexually assaulted a child by the name of X (NRIC: 081128-13-0822) to wit, by touching your penis to her vagina, licking her vagina, squeezing and sucking her breast but without having sexual intercourse with her. Thereby you have committed an offence punishable under Section 14(d) of the Sexual Offences Against Children Act 2017".

Section 14(d) (Sexual Offences Against Children Act 2017 (Act 792)) provides that "any person who, for sexual purposes, does any other acts that involve physical contact with a child without sexual intercourse..." This section does not specify an offence with a specific name but defined the offence under section 14(d). The offence under this section requires a sexual act involving physical touches performed by someone on children without sexual intercourse. This kind of act is an offence under section 14(d). Basically, this Act (Sexual Offences Against 
Children Act 2017 (Act 792)) discusses three forms of sexual assaults on children. Part II discusses the offences relating to child pornography. Whereas Part III discusses offences regarding child sexual grooming, and Part IV provides offences relating to sexual assault (physical and non-physical) (Norazla Abdul Wahab, 2018). Therefore, the following subtopics will further discuss the elements of each offence.

\subsection{Sections Concerned with the Production, Distribution and Viewing of Child Pornography}

Section 4 to section 10, which is under Part II of the Act, is concerned with the production, distribution, and viewing of child pornography. Section 4(a) of the Sexual Offences Against Children Act 2017 (Act 792) defines child pornography as any representation, whether visual, audio or written or the combination of visual, audio or written, or by any other means:

1) of a child engaged in sexually explicit conduct;

2) of a person appearing to be a child engaged in sexually explicit conduct;

3) of realistic images of a child engaged in sexually explicit conduct; or

4) of realistic images of a person appearing to be a child engaged in sexually explicit conduct;

The definition of pornography has been taken from Article 9 of the Budapest Convention (European Treaty Series - No. 185), which defines child pornography as:

a) producing child pornography for the purpose of its distribution through a computer system;

b) offering or making available child pornography through a computer system;

c) distributing or transmitting child pornography through a computer system;

d) procuring child pornography through a computer system for oneself or for another person;

e) possessing child pornography in a computer system or on a computer-data storage medium. (Article 9, Budapest Convention (European Treaty Series - No. 185))

While the term "child pornography" shall include pornographic material that visually depicts a minor engaged in sexually explicit conduct, the term includes a person appearing to be a minor engaged in sexually explicit conduct or realistic images representing a minor engaged in sexually explicit conduct (Malaysia, Perbahasan Dewan Rakyat, Bacaan Kedua dan Ketiga, 4 April 2017, 26 (Dato' Sri Azalina Dato' Othman Said)). Part II of the Act also lists a number of offences related to pornography as set out in Table 1.

Table 1. Offences relating to pornography

\begin{tabular}{|c|c|}
\hline Section & Offences \\
\hline 5 & $\begin{array}{l}\text { Makes, produces, directs the making or production of, or participates in the making of child } \\
\text { pornography. }\end{array}$ \\
\hline 6 & $\begin{array}{l}\text { Makes any preparation to make, produce or direct the making or production of any child } \\
\text { pornography. }\end{array}$ \\
\hline 7 & $\begin{array}{l}\text { Uses or causes a child to be used in the preparation to make or directing to the making or } \\
\text { production of any child pornography. }\end{array}$ \\
\hline 8 & $\begin{array}{l}\text { Exchanges, publishes, sells, distributes, advertises, imports and exports, any } \\
\text { child pornography; }\end{array}$ \\
\hline 9 & Sells any child pornography to a child. \\
\hline 10 & Accesses, or has in his possession any child pornography. \\
\hline
\end{tabular}

Briefly, Part II provides for a ban on using children or exploit children in the preparation process or act to do, produce, direct the manufacture or production of child pornography (Norazla Abdul Wahab, 2018). It also includes the collection, publication and sale or participation in or receiving profits from the sale of child pornography, including pornographic material or have access to it (Norazla Abdul Wahab, 2018). A person is said to have accessed child pornography if he saw child pornography or material sent to him (Norazla Abdul Wahab, 2018).

Therefore, any offence to be charged under section 4 until section 10 of the Act must clearly state the kind of act committed by the offender, which amounts to pornography as stated by the sections above. 


\subsection{Sections Related to Child Grooming}

Meanwhile, part III of the Act provides for the punishment for offences relating to child grooming. Grooming is the process by which paedophiles transition a child from a non-sexual relationship to a sexual one in a way that appears natural and non-threatening to the child or even to an adult supervising the child. (Manique Cooray, 2016). It is through this 'process' that paedophiles seek out, befriends and manipulate a targeted child for the production of child pornography (Manique Cooray, 2016). In other words, 'grooming' is the 'gradual process a skilled paedophile takes in laying a foundation of trust, love and friendship before escalating the relationship to that of a sexual nature.' Ultimately, a seemingly healthy relationship is used to take sexual advantage of a vulnerable child (Manique Cooray, 2016).

Section 12, 13 and 14 of the Act Sexual Offences Against Children Act 2017 (Act 792) describe the method of restructuring (sexual grooming) of a child, starting with a sexual communication by the offenders or encouraging the child to communicate sexually. The development process follows this and subsequently ended with a meeting between offenders and the child (Norazla Abdul Wahab, 2018). Table 2 describes the process and offences related to child grooming.

Table 2. Offences relating to child grooming

\begin{tabular}{ccl}
\hline \multicolumn{1}{c}{ Process } & Section & \multicolumn{1}{c}{ Offence } \\
\hline Communication & 11 & $\begin{array}{l}\text { Sexually communicates with a child or encourages a child to sexually } \\
\text { communicate, } \\
\text { Grooming }\end{array}$ \\
Meeting & $12 \quad \begin{array}{l}\text { Communicates by any means with a child with the intention to commit or } \\
\text { to facilitate the commission of any offence under sections } 5,6,7,8,15 \text { or } \\
16 \text { or any offence under the Schedule against the child. } \\
\text { Having communicated by any means with a child meets with the child with } \\
\text { the intention to commit or to facilitate the commission of any sexual } \\
\text { offence. }\end{array}$ \\
\end{tabular}

Under section 12, the element that must be proven is the sexual word. There is a possibility that the word uttered, in A's opinion, is not sexual, but for B, it is sexual. This is subjected to the circumstances and is up to the judge to decide (Malaysia, Perbahasan Dewan Rakyat, Bacaan Kedua dan Ketiga, 4 April 2017, 54 (Dato' Sri Azalina Dato' Othman Said)). Despite that, it is important to state clearly the word uttered by the accused in the charge so that the accused would know the offence committed. Whereas in the case of child grooming under section 13, the communication by the accused with an intent to commit the said offence must be proven (Malaysia, Perbahasan Dewan Rakyat, Bacaan Kedua dan Ketiga, 4 April 2017, 54 (Dato' Sri Azalina Dato' Othman Said)). Therefore, it is important in the charge to make it clear that the kind of communication by the accused led to the accused's intention to commit sexual offences.

\subsection{Section That Covers Sexual Assault on Minors}

The third offence discussed in part IV of the act is sexual assault. This offence is divided into physical sexual assault and non-physical sexual assault on a child. Table 3 describes offences relating to sexual assault. 
Table 3. Offences relating to sexual assault

\begin{tabular}{l}
\hline Section \\
\hline 14 \\
Physical sexual assault on a child: \\
(a) touches any part of the body of a child; \\
(b) makes a child touch any part of the body of such person or of any other person; \\
(c) makes a child touch any part of the child's own body; or \\
(d) does any other acts that involve physical contact with a child without sexual intercourse? \\
Non-physical sexual assault on a child: \\
(a) utters any word or makes any sound, or makes any gesture or exhibits any object or his \\
(b) makes a child exhibit the child's body so as it is seen by such person or any other person; \\
(c) repeatedly or constantly follows or watches or contacts a child by any means; \\
(d) threatens to use any representation, whether visual, audio or written, any part of the body \\
(e) engages in an activity that is sexual in nature in the presence of a child; \\
(f) causes a child to watch another person engaging in an activity that is sexual in nature; \\
(g) makes a child engage in an activity that is sexual in nature,
\end{tabular}

Any offence to be charged under section 14 and section 15 of the Act must clearly state the kind of act of the offender which amounts to sexual assault. For example, in the case of Hisyamudin bin Ahmad lwn Pendakwaraya [2019] MLJU 328. The charge read as follow:

"Bahawa kamu pada 8 November 2017 jam lebih kurang 8.00 malam sehingga 9.00 malam, di No. 1 Jalan Mewah Kampung Melayu Majidee di dalam daerah Johor Bahru, di dalam negeri Johor telah melaku amang seksual fizikal ke atas Nur Balqis Batrisya binti Hishamudin, No. K/P: 081104-01-1458 dengan cara menyentuh kemaluannya. Oleh itu kamu telah melakukan suatu kesalahan yang boleh dihukum di bawah seksyen 14(a) Akta Kesalahan-Kesalahan Seksual Terhadap Kanak-Kanak 2017 dibaca bersama seksyen 16 Akta yang sama."

In this charge, the first requirement of a valid charge is already fulfilled. The next requirement of a valid charge is that the law and section of the law against which the offence is said to have been committed shall be mentioned in the charge (Section 152(4) of Criminal Procedure Code (Act 593)). In the High Court case of Pendakwa Raya v Lee Tee Maw (1991) 2 CLJ 86, Abdul Aziz J stated that (at page 88):

"Berkenaan dengan kecacatan pada pertuduhan pula, sebagaimana saya nyatakan tadi, ia menyebut s. 107(6) Akta Kerajaan Tempatan 1976 sebagai undang-undang yang dilanggar dan s. 119 sebagai seksyen penaltinya. Tetapi seksyen 107(6) memperuntukkan penalti bagi kesalahan tidak mempamerkan lesen. Oleh yang demikian pertuduhan itu adalah salah apabila ia menyatakan bahawa menjalankan perniagaan hotel tanpa lesen melanggar s. 107(6) atau apabila ia gagal menyatakan apakah undang-undang sebenarnya yang dilanggar. Maka kehendak s. 152(iv) Kanun Tatacara Jenayah telah tidak dipatuhi.”

The failure to state the correct section and law is a vital defect to the charge. Based on the above-mentioned examples of charges, it can be seen that the charges had sufficed a valid charge as it contains the offence of the accused, and it states the law and the section of the law against which the offence is said to have been committed.

\section{Effect of Defects of Charge and How to Cure It under Section 422}

Section 422 of the CPC is a very wide provision that remedies all forms of irregularities, error, omission or improper admission or rejection of evidence unless it has occasioned a failure of justice. Defects in the charging document may be challenged by a dismissal motion. The prosecution must have persuaded the court that the conclusions reached were reasonable grounds to infer that the charged offence happened, and that the defendant committed it (Charge, 2019). 


\subsection{Irregularities not to Vitiate Proceedings}

Section 422 of the Criminal Procedure Code states subject to the provisions contained in this Chapter, no finding, sentence, or order passed or made by a Court of competent jurisdiction shall be reversed or altered on account of:

(a) any error, omission or irregularity in the complaint, sanction, consent, summons, warrant, charge, judgment or other proceedings before or during the trial, or in any inquiry or other proceedings under this Code;

(b) the want of any sanction; or

(c) the improper admission or rejection of any evidence, unless such error, omission, irregularity, want, or improper admission or rejection of evidence has occasioned a failure of justice (section 422 Criminal Procedure Code (Act 593)).

A motion to dismiss a complaint or charge must normally be filed before trial because a charge that fails to state an offence must be dismissed whenever the defect is noticed. The grounds of an arbitrary criminal statute cannot be the ground for a penalty even though the defects are apparent. It follows that counsel may raise statutory defects, such as excessive vagueness or violation of equal protection (Stanley Z. Fisher, 2019). However, section 156 of the CPC states that not mentioning the particulars under section 152-154 CPC do not necessarily render the charge as defective. This is because as long as the accused is not misled by the error in the charge, the accused could still defend himself. The illustration under this section shows that: -

$A$ is charged with cheating $B$, and the manner in which he cheated was incorrectly set out in the charge. He defends himself, calls witnesses and gives his own account of the transactions. The court may infer that the omission is to set out that the manner of the cheating is immaterial. (Illustration (b), Section 156 Criminal Procedure Code)

Section 156 of the CPC states that there is no error in declaring either the offence or the particulars necessary to be stated in the charge and that no omission to state the offence or those particulars shall be considered relevant at any stage of the case unless the accused was actually deceived by such error or omission (section 156 Criminal Procedure Code). However, based on section 157 of the CPC, the High Court may permit or direct the framing of a charge or add to or alter an imperfect or erroneous charge. In addition, Section 158 states that any court may alter or add to any charge at any time before the judgement and that every alteration or addition must be read and explained to the accused in person.

In the case of Baharudin Kulop v PP [2019] 1 LNS 129, the accused had been charged for committing rape on his stepdaughter at his residence pursuant to section 376(3) of the Penal Code. The elements in the charge did not meet all of the legal requirements for the offence. Furthermore, since a charge is a specific allegation against the accused that he committed a crime known in law as rape, it is only reasonable that the allegation is phrased as a single sentence with suitable punctuation. The accused was charged with three separate punishments, all of which the judge deemed improper. The elements in the charge did not meet all of the legal requirements for the offence. The accused was charged with 3 separate punishments, all of which the judge deemed improper. Therefore, it has to be only one allegation against the accused person. This is pursuant to section 152(2) CPC, since the offence is "rape" as described in section 375 CPC.

Initially, the court considered it to be an error because it does not convey to the accused with certainty what the prosecution intends to prove against him. This is because he will have to defend himself and exculpate himself. However, the accused was not denied his rights to defend himself freely and not restrained with the aid of lawyers. The accused was brought to trial and defended by a counsel appointed by the National Legal Aid Foundation (Yayasan Bantuan Guaman Kebangsaan (YBGK). Therefore, he is not deceived by the charge's failure, and it did not result in the accused experiencing injustice. Section $156 \mathrm{CPC}$, read in conjunction with section $422 \mathrm{CPC}$, supports this. Section 422 states that no finding, sentence or order passed or made by a Court of competent jurisdiction shall be reversed or altered on account of any irregularity unless there is a failure to justice. For that reason, a charge is only considered defective if the accused was misled by it and can only be cured under section 422 of the Criminal Procedure Code if the accused was deceived by the charge's failure.

While, in the case of Abou Soulla v PP [2018] 1 CLJ 46, the accused's complaint was that there was no indication in the judgment of the trial judge as to whether the accused was convicted based on actual trafficking or presumed trafficking. The accused argued that the omission on the part of the trial judge to state whether it was a case of direct trafficking or presumed trafficking was erroneous and fatal. The court held that there was a misdirection by the learned trial judge because of his failure to state whether the conviction of the accused was based on actual or presumed trafficking. The issue, in this case, is whether it can be cured under Section 422 of the Criminal Procedure Code. In this case, it was held that the failure of the learned trial judge to state whether it was direct or presumed 
trafficking was a serious misdirection in law. The misdirection in law had occasioned a miscarriage of justice to the accused person. In this case, the benefit of doubt must be given to the accused if there exists a reasonable doubt regarding whether the accused had a fair trial, whether he knew what he was being tried for and whether the allegations and facts were explained to him fairly and clearly and whether he was given a full and fair chance to defend himself. Hence, this case showed that Section 422 of the Criminal Procedure Code be used only when there is a failure of justice and a serious misdirection in law to the accused.

Thus, it can be concluded that the Criminal Procedure Code is a very extensive act that covers all types of irregularity, mistake, omission or improper admission or denial of facts unless it has caused a miscarriage of justice. This means that the Criminal Procedure Code specifies that there is no mistake in specifying either the crime or the information needed to be stated in the charge, and no failure to state the offence or such details shall not be considered as evidence at any point of the case unless the error or omission has personally deceived the defendant. If the Court found that the irregularities were insufficient to vitiate the proceedings, the evidence is untainted by the irregularities that fell short of proving guilt beyond a reasonable doubt. However, if there is a violation of the right to a fair trial, there will be a miscarriage of justice, and attention will be extended to the irregularity.

\section{Conclusion}

In a nutshell, criminal profiling is very vital for framing the charge. A charge, which is a formal statement of an accusation made against the accused serves as a notification about the accusation to the accused. There are requirements that must be borne in mind when a charge is drafted. In order to answer the question of whether a defect in the charge involving sexual offences under the Penal Code (Act 574) and the relatively new Sexual Offenses Against Children Act 2017 (Act 792) would render the charge fatal to the prosecution's case, a case-tocase analysis was made. The rationale behind the varying strict and loose approaches by the Malaysian and foreign courts towards the types of defects in the charges was analysed as well.

The outcome of the analysis suggests that the courts consider the importance of a charge complying with the requirements set by the laws regulating the framing of charges. However, defects in charges are not necessarily fatal to the prosecution's case. There are situations where the defect has related to a requirement that does not constitute the essential ingredient of the said offence. In such instances, Section 422 of CPC is used to cure the irregularities.

With regard to criminal profiling, the ideal way to handle the cases of sexual offences with defective charges, in our opinion, is to treat minor defects as mere irregularities. This approach is applicable in instances when the defect will not result in the miscarriage of justice. Those who are entitled to justice cannot be denied their right solely because of procedural non-compliance. The technicalities of the law and the procedural laws are of great importance, but they cannot be allowed to be the obstruction of justice.

\section{Acknowledgement}

The authors wish to thank the Ministry of Higher Education (Malaysia) for providing the research grant funding under Fundamental Research Grant Scheme (FRGS), FRGS/1/2020/SSI0/UKM/02/19

\section{References}

Ab Malek bin Atan v PP [2002] 4 MLJ 84.

Abou Soulla v PP [2018] 1 CLJ 46.

Baharudin Kulop v PP [2019] 1 LNS 1295.

Baljit, S. S. (2015). Criminal Litigation Process (3rd ed.). Sweet \& Maxwell, Malaysia.

Budapest Convention (European Treaty Series - No. 185).

Charge. (2019). Content, Consequence of Defect in the Framing Charge. Retrieved November 15, 2019, from $\mathrm{http} / /$ www.legalserviceindia.com/legal/article-350-charge-content-consequence-of-defect-in-the-framingcharge.html

Cooray, M. (2017). Sexual Offences against Children Bill 2017(Malaysia): Some Observations. Malayan Law Journal, 3.

Criminal Procedure Code (Act 593).

Dato' Seri Anwar Ibrahim v. PP \& Another Appeal [2004] 3 CLJ 737.

Helerry Bungkok v PP [2019] 10 MLJ 308.

Hisyamudin bin Ahmad lwn Pendakwaraya [2019] MLJU 328. 
Jagar Singh v PP [1936] MLJ 114.

Krishnan \& Anor v Public Prosecutor [1981] 2 MLJ 121.

Law Kiat Lang v PP [1965] 1 MLRA 297; [1966] 1 MLJ 215.

Malaysia, Perbahasan Dewan Rakyat, Bacaan Kedua dan Ketiga, 4 April 2017, 26 (Dato' Sri Azalina Dato' Othman Said).

Manique, C. (2016). The Need for 'Anti-Grooming' Laws to Regulate Child Pornography on The Internet and The Penal Code of Malaysia: A time for Review. Malayan Law Journal, 6.

Mohamad Rizal Romlee v Pendakwa Raya [2017] MLRHU 434.

Mohd Hanif Kassim v PP and Another Appeal [2015] 3 CLJ 984.

Mohd Ikhsan bin Ramli v Pendakwa Raya [2018] MLJU 2071.

Mohd Khairul Hisam Azis v PP [2019] MLRHU 321.

Mustafha Bin Abdul Razak v Pendakwa Raya [2017] MLJU 1723.

Norazla, A. W. (2018). Akta Kesalahan-Kesalahan Seksual Terhadap Kanak-Kanak 2017: Penambahbaikan Perundangan Berkaitan Jenayah Seksual Terhadap Kanak-kanak di Malaysia. Journal of Muwafaqat, 1(1).

Penal Code (Act 574).

Pendakwa Raya v Lee Tee Maw (1991) 2 CLJ 86.

PP v Dato’ Seri Anwar Ibrahim \& Anor [2001] 3 CLJ 313.

PP v Lee Pak [1937] MLJ 265.

PP v. Chettuvelu Nani [2007] 9 CLJ 533; [2007] 6 MLJ 621.

Public Prosecutor v Chung Tshun Tin \& Ors [2008] 1 MLJ 559.

R v Mohamed Humayoon Shah (1874) 21 WR Co 72.

R v Rider [1954] 1 All ER 5.

R v Severo Dossi [1918] 13 Cr App R 158.

Rama Krishnan a/l Nallapuravu lwn Pendakwa Raya [2018] MLJU 1114.

Ratanlal and Dhirajlal. (1997-1998). Law of Crimes, New Delhi: Bharat Law House (24th ed.).

Ravindran Ramasamy [2015] 3 CLJ 421.

Rosli, N., Zubaidi, N. H. A., \& Dusuki, F. N. (2019). Regulating the Protection and Rehabilitation of Victims of Internet Child Pornography in Malaysia. International Journal of Academic Research Business and Social Sciences, 9(5). https://doi.org/10.6007/IJARBSS/v9-i5/5887

Sexual Offenses Against Children Act 2017 (Act 792).

Shah Reza Bin Zulkifli \& Ors v Pendakwa Raya [2016] MLJU 576.

Stanley Z. Fisher, Chapter 20, Defects in the Complaint or Indictment, page 4.

VC Shukla v State through CBI 1980 Cri LJ 690.

\section{Copyrights}

Copyright for this article is retained by the author(s), with first publication rights granted to the journal.

This is an open-access article distributed under the terms and conditions of the Creative Commons Attribution license (http://creativecommons.org/licenses/by/4.0/). 